\title{
The potential role of adiponectin- and resistin-like peptides in the regulation of lipid levels in the hemolymph of over-wintering adult females of Osmia bicornis
}

\author{
Oskar Wasielewski ${ }^{1}$, Dawid Szczepankiewicz ${ }^{2}$, Karol GieJdasz ${ }^{1}$, \\ Tatiana WoJCIECHOWICZ ${ }^{2}$, Andrea BednÁŘoví ${ }^{3,4}$, Natraj Krishnan ${ }^{3}$ \\ ${ }^{1}$ Institute of Zoology, Poznań University of Life Sciences, Wojska Polskiego 71C, 60-625 Poznań, Poland \\ ${ }^{2}$ Department of Animal Physiology and Biochemistry, Poznań University of Life Sciences, Wojska Polskiego 35, \\ 60-637 Poznań, Poland \\ ${ }^{3}$ Department of Biochemistry, Molecular Biology, Entomology and Plant Pathology, Mississippi State University, \\ Mississippi State MS 39762, USA \\ ${ }^{4}$ Institute of Entomology, Biology Centre, Academy of Science and Faculty of Science, South Bohemian University, \\ Branišovská 31, České Budějovice 370 05-CZ, Czech Republic
}

Received 23 September 2013 - Revised 26 November 2013 - Accepted 11 December 2013

\begin{abstract}
The presence and potential role of adiponectin- and resistin-like peptides in mobilizing free lipids of hemolymph during over-wintering was studied in females of the European solitary red mason bee Osmia bicornis L. (Hymenoptera: Megachilidae). The levels of both peptides (as demonstrated both by RIA/ELISA and Western blots) were highest in fat body tissue homogenates during early pre-wintering (September) followed by a gradual and significant decline during wintering and post-wintering months (November-March). There was a gradual reduction of the lipid levels in hemolymph and adiponectin-like and resistin-like peptide content in fat body. Thus, the total lipid content in hemolymph and the adiponectin-like and resistin-like peptides in fat body homogenates was positively correlated. Our experiments also demonstrated that injections of various concentrations of fat body extracts as well as various doses of adiponectin and resistin increased the lipid levels in hemolymph in O. bicornis females at the three different periods of over-wintering time. In particular, injections of fat body extract and adiponectin resulted in the strongest mobilization of lipids especially in the first two periods of over-wintering: pre-wintering and wintering. Resistin also elicited an increase of lipid levels in hemolymph, but its effectiveness was lower compared to fat body extract and adiponectin. Taken together, our results strongly suggest the presence of adiponectin-like and resistin-like peptides in the fat body of $O$. bicornis and postulate a dynamic physiological role for these peptides during the process of over-wintering.
\end{abstract}

adiponectin / diapause / free lipids / hemolymph / Osmia bicornis / over-wintering / resistin / solitary bee

\section{INTRODUCTION}

Diapause is a strategy to survive seasons with environmental conditions that are inadequate for

Corresponding author: O. Wasielewski, oskarw@au.poznan.pl

Manuscript editor: Monique Gauthier sustaining continuous development or maintenance of the organism (Denlinger 2002). Depending on the species, diapause can occur in one or sometimes several developmental stages: as eggs, larvae, pupae or adults (Tatar and Yin 2001). In insects, an adult diapause is a unique type of quiescence observed which involves the arrest of reproductive development. 
The shortening of the day length in autumn coupled with the lowering of temperature is sufficient to induce adult diapause in many insects (De Wilde et al. 1968; Rust et al. 1989; Krafsur et al. 1999; Herman and Tatar 2001), whereas in several Osmia species, it is dependent on temperature and independent of photoperiod (Bosch and Kemp 2000; Bosch et al. 2010; Sgolastra et al. 2010).

Both diapausing and direct-developing insects store metabolic reserves of the same three macronutrients groups: lipids, carbohydrates and amino acids, as well as essential micronutrients such as vitamins and minerals (Hahn and Denlinger 2011). In insects that diapause as adults, nutrient reserves accumulated in fat body prior to diapause are critical for restoring post-diapause functions, including the rebuilding of tissues atrophied as part of the diapause programme and for providing energy for post-diapause activities, such as dispersal and reproduction (Hahn and Denlinger 2007). Triacylglyceride fat stores are the most common energy reserve in most diapausing insects, often accounting for as much as $80-95 \%$ of the total lipid content (Arrese and Soulages 2010). They are important because of their high caloric content, low hydration state and perhaps relatively high yield of metabolic water. The fat body is the primary site of fatty acid synthesis, triacylglyceride production and triacylglyceride storage in insects, although all cells can store some triacylglycerides and substantial stores can occur in tissues such as the large, metabolically active flight muscles (Zera and Denno 1997). Managing metabolic resources such as lipids but also carbohydrates and amino acids is critical for insects during diapause when food is limited or unavailable. An adequate nutrient utilization promotes tiding over the diapause period and enables post-diapause development (Macrae 2005). The range of information about hormonal regulation in these processes is limited. However, for example, Hahn and Denlinger (2007) propose that the adipokinetic hormones (AKHs) could contribute to diapauseassociated alteration in metabolism. AKHs comprise a family of peptide hormones that are synthesized, stored and released predominantly by neurosecretory cells of the corpora cardiaca (CC), neuroendocrine glands connected to the brain (Gäde et al. 1997). The most widely recognized action of the AKH family of peptides is their role for mobilizing carbohydrates, lipids and the amino acid proline from reserves to support the extreme energetic demands of insect flight (Gäde and Auerswald 2003; Gäde 2004), but recent physiological and genetic studies in Drosophila melanogaster and Bombyx mori suggest that AKHs may also play roles in nutrient homeostasis, particularly blood sugar regulation (Satake et al. 2000; Kim and Rulifson 2004; Isabel et al. 2005). However, evidence of the involvement of $\mathrm{AKH}$ in diapause metabolism is currently limited to one study (Socha and Kodrík 1999).

At the functional level, AKHs resembles the vertebrate peptide hormone, glucagon (Alquicer et al. 2009; Bednáŕová et al. 2013). Other vertebrate candidates whose function can be compared with AKHs are adiponectin (Tsao et al. 2002) and resistin (Holcomb et al. 2000), peptide hormones discovered in the last decade from vertebrate adipose tissue, which modulate a number of metabolic processes, including glucose regulation and fatty acid catabolism (Diez and Iglesias 2003; Nogueiras et al. 2010). The primary structure of adiponectin ( $\mathrm{MW}=25-$ $35 \mathrm{kDa}$; Diez and Iglesias 2003) and resistin $(\mathrm{MW}=12.5 \mathrm{kDa}$; McTernan et al. 2006) differs substantially from that of members of the AKH family (Kodrík et al. 2010). Moreover, there is no information available on adiponectin-like and resistin-like peptides or their activity in insects.

Some basic information on the biology of over-wintering solitary bee, Osmia bicornis L. is available from certain European countries (Tasei 1973a, b; Wójtowski 1979; Hallmen 1988; Kristjansson 1992). The red mason bee, O. bicornis, is a univoltine species, which completes its development from egg to the imago stage in the spring and in the summer season (Giejdasz and Wilkaniec 2002; Wilkaniec and Giejdasz 2003). Adults emerge in September and overwinter as imago inside a 
cocoon through the winter months (Giejdasz and Wilkaniec 2002). In natural conditions, as in other species of the Osmia genus, the bees eclose the subsequent spring as the temperature rises (Bosch and Kemp 2000). A lot of information is available on diapause of the spring-flying solitary bee from North America O. lignaria (Sgolastra et al. 2010; Bosch et al. 2010). However, the timing of entering diapause, its maintenance and diapause termination is different in O. bicornis (Wasielewski et al. 2011a). O. bicornis enters diapause in November (based on staging of ovarian development) and diapause termination occurs at the end of January. Then, the imago remains in post-diapause quiescence till April (Wasielewski et al. 2011b). This interpretation of the timing of diapause events is based on both physiological and ecological parameters (Koštál 2006).

There is a paucity of information about the physiological processes used by diapausing solitary bees to assess their nutrient reserves and regulate nutrient utilization. Thus, the objectives of this study were two-fold: to (1) identify the presence of peptides other than $\mathrm{AKH}$ involved in metabolizing lipids during diapause and (2) elucidate the physiological role of these peptides in managing metabolic resources during diapause. This is particularly important in case of a solitary bee such as $O$. bicornis since very little is known about the physiological regulation of diapause in this insect.

\section{MATERIAL AND METHODS}

\subsection{Experimental animals}

Experiments were conducted in the years 20112013 during the wintering period of $O$. bicornis. The experimental material consisted of bees reared in artificial nests made of reed stalks following the method of Wójtowski and Wilkaniec (1978) and originated from nests kept in natural conditions in the botanical garden near the Institute of Zoology (Poznań, Poland). The experiments started after bees reached adulthood (beginning of September) and were completed in March before the emergence period. The experimental material was collected once in the middle of the appropriate month. Thus, adults were collected as pre-wintering, wintering and postwintering, and the demarcation and categorization was based on ovarian development stages as described previously (Wasielewski et al. 2011a, b). Prior to conducting all experiments, reed stalks from the nests were brought and dismantled in the laboratory. Cocoons were transferred to Petri dishes, dissected and adults were sexed according to morphological characters. For all biochemical assays, we only used females for the following biological reason: firstly, wintering adult males accumulated less fat body relative to females which follows from the specificity of their development during diapause. On the other hand, the females accumulate far more fat body reserves with a huge amount of energy substrates necessary not only for successful wintering, including diapause but also for completing their ovarian development during post-diapause period (Wilkaniec et al. 2004). From each female, the fat body, gut, muscles and brain (for adiponectin and resistin assay) and hemolymph (for lipid content) were collected and appropriate analyses were conducted according to the methods described below.

\subsection{Radio immunoassay for adiponectin-like peptides}

A known quantity (pre-weighed) of fat body tissue was homogenized separately in $300 \mu \mathrm{L}$ of ice-cold saline $\left(130 \mathrm{mM} \mathrm{NaCl}, 1.3 \mathrm{mM} \mathrm{KCl}, 0.9 \mathrm{mM} \mathrm{CaCl}_{2} \cdot 2\right.$ $\mathrm{H}_{2} \mathrm{O}, 1.9 \mathrm{mM} \mathrm{MgCl}{ }_{2} \bullet 6 \mathrm{H}_{2} \mathrm{O}, 2 \mathrm{mM} \mathrm{NaHCO}{ }_{3}$. Homogenates were centrifuged at $10,000 \mathrm{~g}$ for $3 \mathrm{~min}$ and supernatant collected and stored at $-80{ }^{\circ} \mathrm{C}$ until use. Adiponectin concentration was measured using a specific RIA kit for mouse (Millipore Billerica, MA, USA) on a Wallac 1470 gamma counter (Perkin Elmer Life Scence, Wallac Oy, Finland), according to the manufacturer's protocol. One hundred microlitres of supernatant was used for the assay. On the first day, a mix of samples and standard curve with ${ }^{125}$ I-adiponectin and adiponectin antibody was prepared. After that, samples were incubated overnight at room temperature. On the second day of experiment, rabbit carrier and precipitation reagent were added. After that, samples were 
centrifuged for $20 \mathrm{~min}$ at $5,000 \mathrm{~g}$ in $4{ }^{\circ} \mathrm{C}$. The sensitivity of the assay was $0.78 \mathrm{ng} / \mathrm{mL}$. In order to confirm or exclude that the immunoreactivity is restricted to the adipose tissue beyond the fat body tissue, three other tissues were also collected: muscles, gut and brain and the RIA test was performed as described above.

\subsection{ELISA for resistin-like peptides}

For analysis of resistin-like peptides, the fat body tissue homogenates was prepared as described above. Resistin concentration was measured using a specific ELISA kit for mouse (Millipore Billerica, MA, USA) according to ELISA protocol. Ten microlitres of supernatant, standards in duplicate and quality control has been added to the plate. After that, plate was incubated for $1 \mathrm{~h}$ at room temperature. Wells were washed three times by use of wash buffer supplied with the kit, and detection antibody was added. Plate was washed again, and enzyme solution was added. After that, wells were washed and substrate solution was added for $20 \mathrm{~min}$. The measurement was conducted using a Synergy 4 microtiter plate reader (Bio-Tek, VT, USA). Data were analysed using Gen5 software (V. 2.0). The sensitivity of the assay was $0.78 \mathrm{ng} / \mathrm{mL}$. Similar to RIA test for adiponectin, in resistin determination, three others tissue except fat body were used: muscles, gut and brain and ELISA test was performed.

For both adiponectin and resistin assays, fat bodies were sampled from approximately 65 individuals (varying from 7 to 16 individuals per month).

\subsection{Western blots for adiponectin and resistin}

To confirm the presence of adiponectin- and resistinlike peptides in the fat body of $O$. bicornis, tissue homogenates from three different periods of overwintering (pre-wintering: September, wintering: January and post-wintering: March) were equalized for protein content $(25 \mu \mathrm{g})$ and were separated by polyacrylamide gel electrophoresis (SDS-PAGE) on $7.5 \%$ resolving gel (Laemmli 1970) followed by transfer onto PVDF Immobilon membranes overnight at $4{ }^{\circ} \mathrm{C}$ at a constant voltage of 10 and then $25 \mathrm{~V}$ for $1 \mathrm{~h}$. Membranes were blocked for $2 \mathrm{~h}$ using $5 \%$ skimmed milk (BioRad) in phosphate buffered saline with tween
20 (PBST) and incubated overnight with primary antibody [1:5,000, anti-mouse adiponectin polyclonal antibody in rabbit (Millipore AB3269P) or 1:5,000, anti-mouse resistin-like molecule-alpha polyclonal antibody in rabbit (RELM-alpha, Millipore AB3365P)] followed by goat anti-rabbit (IR680) secondary antibody $(1: 20,000)$ tagged with an infrared dye (LI-COR Biosciences). The blots were visualized using fluorescence in an Odyssey Infrared Scanner (Odyssey Clx, LI-COR Biosciences).

\subsection{Hormonal extracts and hormone injections}

The biological activity of methanolic fat body tissue extracts from adults of $O$. bicornis females was tested as follows: a known quantity (pre-weighed) of fat body tissue from pre-wintering, wintering and post-wintering females was collected separately and homogenized in $200 \mu \mathrm{L}$ of extracting solution (methanol: acetic acid: $\left.\mathrm{H}_{2} \mathrm{O} ; 90: 9: 1 \mathrm{v} / \mathrm{v}\right)$. The extract was centrifuged at $10,000 \mathrm{~g}$ for $3 \mathrm{~min}$ and supernatant collected and stored at $-20^{\circ} \mathrm{C}$ until used. For injections, the fat body extracts were dried in vacuum (Eppendorf Concentrator 5301) and re-suspended in saline $(130 \mathrm{mM} \mathrm{NaCl}, 1.3 \mathrm{mM}$ $\mathrm{KCl}, 0.9 \mathrm{mM} \mathrm{CaCl}_{2} \bullet 2 \mathrm{H}_{2} \mathrm{O}, 1.9 \mathrm{mM} \mathrm{MgCl}{ }_{2} \bullet 6 \mathrm{H}_{2} \mathrm{O}$, $2 \mathrm{mM} \mathrm{NaHCO} 3$ ). For tested females, three different concentrations of fat body extracts were used: 50,75 and $100 \%$ of initial concentration. The injection experiments were performed in three different periods of over-wintering: in September (pre-wintering), January (wintering) and March (post-wintering). In each case, fat body extracts from pre-wintering females were injected only to pre-wintering females, extracts from wintering females only to wintering females and so on. For each experiment, a new group of females was used to show the differences in activity and concentration of tested hormones (see Figures 2 and 3). Injections were administered to Osmia females from particular groups only once a day in a volume of $2 \mu \mathrm{L}$ with a $5-\mu \mathrm{L}$ Hamilton syringe (Hamilton Co., Germany). Fat body extracts were injected in given concentration range through the ventral membrane into the hemocoel between the 6th and 7th abdominal tergites. After $24 \mathrm{~h}, 0.5 \mu \mathrm{L}$ hemolymph was collected to determine the effect of the fat body extract on lipid content (Zöllner and Kirsch 1962; Wasielewski et al. 2013). 
The potential role of adiponectin and resistin in hormonal regulation of hemolymph lipids was studied following the injection of peptides into females at the same time as for fat body extracts described earlier. The peptides were injected into the experimental females in three different doses $(50,75,100$ pmol) as described above, and the hemolymph samples were taken $24 \mathrm{~h}$ after the injection for determination of lipids. The peptides adiponectin and resistin were kindly provided by Dr. Maciej Sassek (University of Life Sciences, Poland). Bovine serum albumin (BSA) was administered in a suitable dose $(100 \mathrm{pmol})$ in a manner similar to fat body extracts and tested hormones (adiponectin and resistin) and was used as an internal standard during the experiments.

Thus, for testing the fat body extract and both hormones (adiponectin and resistin) towards their role in hormonal regulation of lipid metabolism, four different controls were used: intact (non-injected), punctured (with Hamilton syringe), saline and BSA injected. Following statistical analysis (one-way ANOVA), we did not observe any statistical differences between control groups $(P>0.05)$. Hence for all subsequent analysis, all other treatments were compared to only saline-injected controls.

\subsection{Statistical analysis}

Data were subjected to statistical analyses using the software package Statistica (Statsoft, v. 9.0). A one-way ANOVA was conducted with post-hoc Tukey test to separate out means within and between data groups (Figures 1, 2 and 3). Correlation (Pearson's correlation coefficient) data were generated for lipid content as dependent variable and adiponectin and resistin as independent variables (Figure 4). Graphs were generated using GraphPad Prism software (v 5.04, La Jolla, CA) and values are presented as mean \pm standard deviations.

\section{RESULTS}

\subsection{Changes in adiponectin-like and resistin-like peptide content of fat body homogenates during over-wintering}

The amount of adiponectin-like and resistinlike peptides in fat body homogenates was highest during pre-wintering (in September) of O. bicornis females (Figure $1 \mathrm{a}, \mathrm{b}$ ). In consecutive months of over-wintering, the concentration of both peptides in fat body homogenates decreased significantly (one-way ANOVA adiponectin-like peptide $F_{6,62}=124.78, P<$ 0.001 ; resistin-like peptide $F_{6,57}=731.90, P<$ 0.001 ) (Figure 1a, b). The first significant decrease (Tukey post-hoc test, $P<0.0001$ ) in the content of both peptides was observed in October (Figure 1a, b). At initiation of diapause (in November), compared to pre-wintering (September-October), the adiponectin-like peptide concentration dropped down dramatically, whereas during diapause and post-diapause quiescence (December-March), the decline in adiponectin-like peptide concentration was slight (Figure 1a). Furthermore, no significant changes in the content of adiponectin were recorded between winter months NovemberMarch (Tukey post-hoc test; $P>0.05$ ). In contrast, a substantial and significant loss of the resistin-like peptide content in fat body homogenates was noted throughout the winter months from November to March (Figure 1b). Significant differences in resistin content between the deep winter months (DecemberMarch $) \quad(P<0.0001)$ was also recorded (Figure 1b).

The presence of adiponectin-like and resistinlike peptides was confirmed by western blots in fat body homogenates of bees collected during pre-wintering (September), wintering (January) and post-wintering (March) (Figure 2a, b).

\subsection{Effect of fat body extracts, adiponectin and resistin on hemolymph lipids}

The experiments demonstrated that the fat body extracts, adiponectin and resistin increase the lipid content in hemolymph of $O$. bicornis females during three different periods of overwintering time (Figure $3 \mathrm{a}-\mathrm{c}$ ). During the prewintering time (September), the response to fat body extract and both injected peptides was dose dependent. The highest increase in lipid content was noted after injection of $100 \%$ of fat body extracts and 100 pmol of adiponectin 
Figure 1 Profiles of

adiponectin-like (a) and

resistin-like (b) peptides in the fat body homogenates of $O$.

bicornis females during overwintering months. Data for each month are mean \pm SD of 7-16 individuals sampled for each peptide. The $y$-axis in (a) has been converted to $\log _{10}$ scale with actual adiponectin concentrations. Bars with different superscripts denote significant differences $(P<0.05)$ using one-way ANOVA followed by Tukey's multiple comparison test

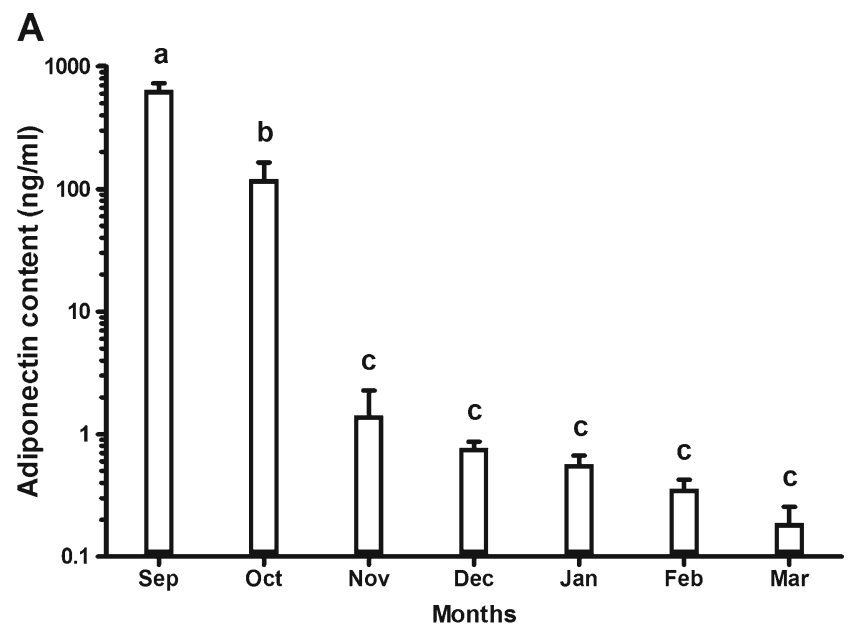

B

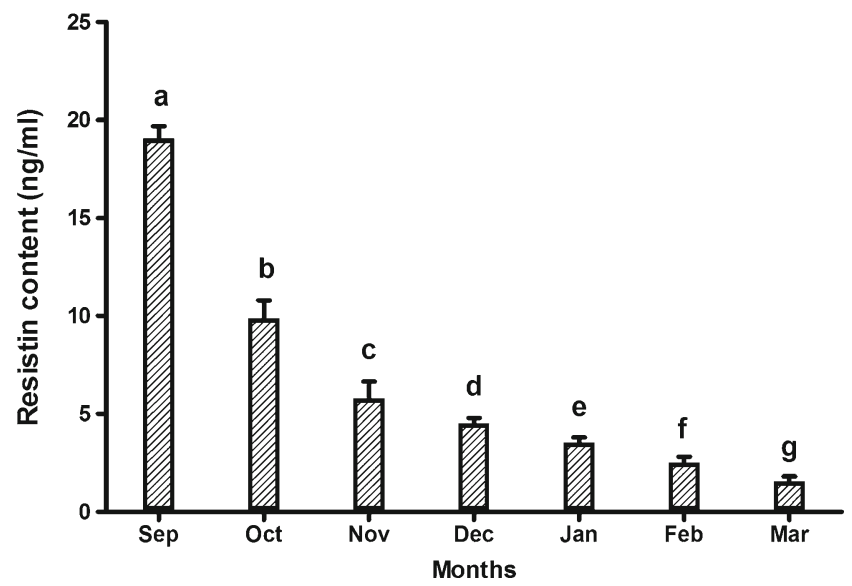

compared with saline controls. For 100 pmol of resistin, the increase of lipids was much lower. In all doses tested, except 50 pmol of resistin, the lipid level in hemolymph was elevated significantly $(P<0.05$; Figure $3 a)$. Similarly to pre-wintering period, injections of fat body extract and as well as both hormones caused significant increase in hemolymph lipid content during wintering (January, $P<0.05$ ) (Figure $3 b$ ). In the following development period, postwintering time (March), the injection effectiveness was extremely poor, even after application of high doses of extract and hormones. Only in the case of 75 and $100 \%$ of extract and 100 pmol of adiponectin, a statistically significant increase in lipid elevation was noted $(P<0.05$; Figure $3 \mathrm{c})$. Injections of the other doses were ineffective and did not induce the expected increase in the hemolymph lipids level $(P>0.05$; compared with saline controls; Figure $3 \mathrm{~b}$ ).

\subsection{Correlation of lipid content in hemolymph with content of peptides adiponectin and resistin in fat body homogenates}

The total lipid content in hemolymph and the adiponectin-like and resistin-like peptides concentration in fat body was positively correlated (Lipid content vs. adiponectin-like peptide, Pearsons $r=0.748, n=66, P<0.0001$; lipid con- 


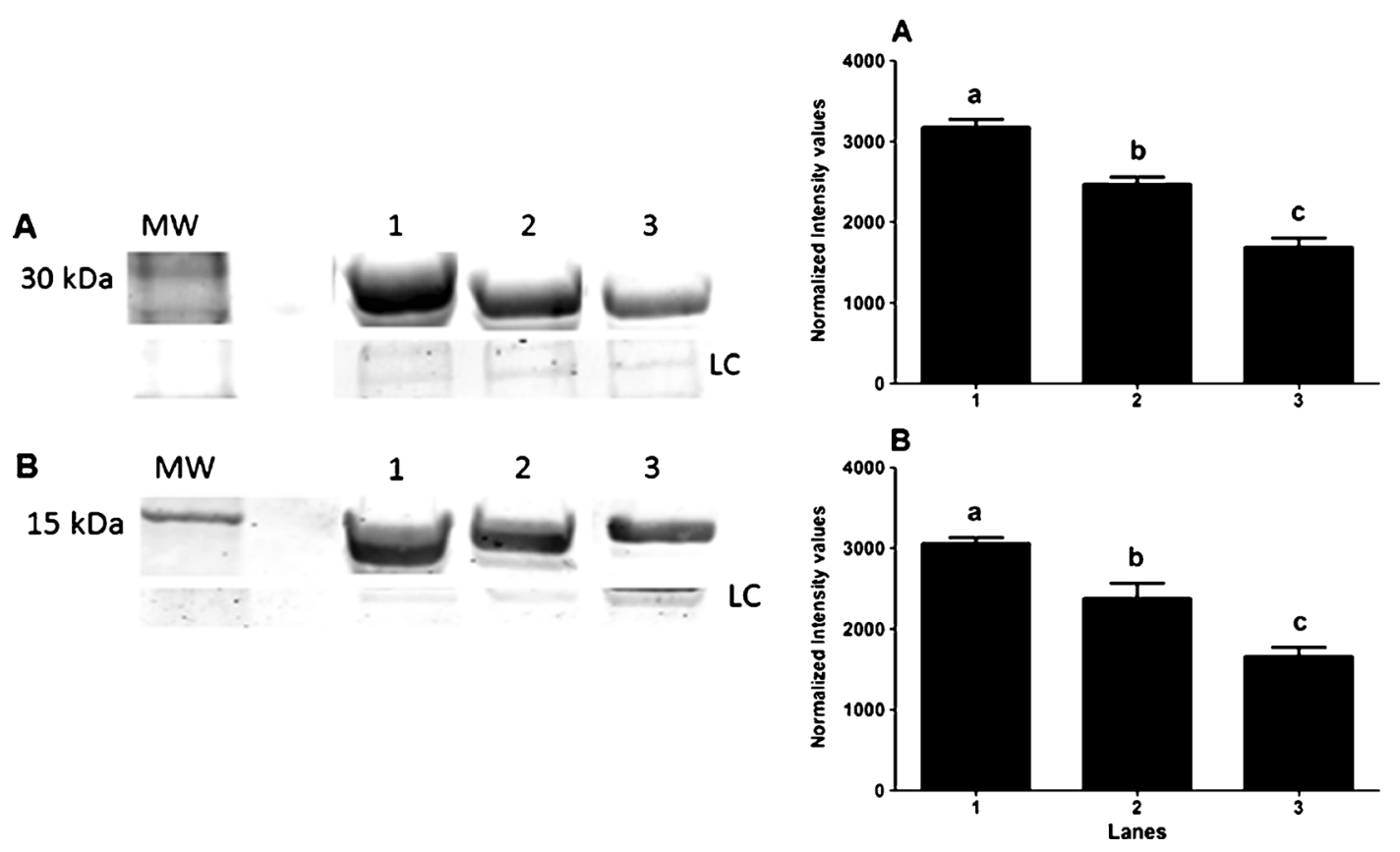

Figure 2 Western blots (on left) of adiponectin-like peptide (a) and resistin-like peptide (b) in fat body homogenates of O. bicornis females. Lane 1: pre-wintering (September), lane 2: wintering (January) and lane 3: post-wintering (March). MW: molecular weight marker and LC: loading control. The blot shown is a representative of three independent blots run for adiponectin- and resistin-like peptides from fat body homogenates from different days of the three periods of over-wintering. On the right are graphs of normalized intensity values (averaged from three separate blots) for adiponectin-like peptide (a) and resistin-like peptide (b). Different superscripts above each bar represents that they are significantly different at $P<0.05$ using oneway ANOVA followed by Tukey's multiple comparison test. (Please see text for additional details of blot)

tent vs. resistin-like peptide, Pearsons $r=0.907$, $n=60, P<0.0001$ ) (Figure 4a, b). Moreover, other than the positive correlation between lipid in hemolymph and both peptides from fat body tissue, a positive correlation between the adiponectin-like and resistin-like peptide concentration in the fat body homogenates was also confirmed (Pearsons $r=0.914, n=52, P<0.0001$, Figure 4c).

\section{DISCUSSION}

In this study, we demonstrate the presence of adiponectin- and resistin-like peptides in the fat body $O$. bicornis during over-wintering. We also postulate a physiological function of these peptides by injecting fat body extract containing these peptides or by directly injecting various concentrations of the hormones into prewintering, wintering and post-wintering bees and documenting changes in free lipid levels in the hemolymph of the bees. To our knowledge, this is the first demonstration of the presence and physiological role of these peptides in insects.

Numerous authors have shown that stored reserves decline during diapause and that individuals experiencing longer diapause periods contain fewer reserves following termination of diapause (Danks 1987). For example, both the fly Calliphora vicina (Saunders 2000) and the parasitoid wasp Asobara tabida (Ellers and van Alphen 2002) diapause as post-feeding larvae, and the fat content of resulting post- 
Figure 3 Profile of free lipid content in hemolymph of $O$. bicornis females during three different periods of overwintering time: a prewintering (September), b wintering (January) and $\mathbf{c}$ postwintering (March) after fat body extracts, adiponectin and resistin injections. Data for each bar are mean \pm SD of 15 individuals sampled. Bars with asterisks denote significant difference $(P<0.05)$ from the control (saline injected) females following one-way ANOVA with post-test
A

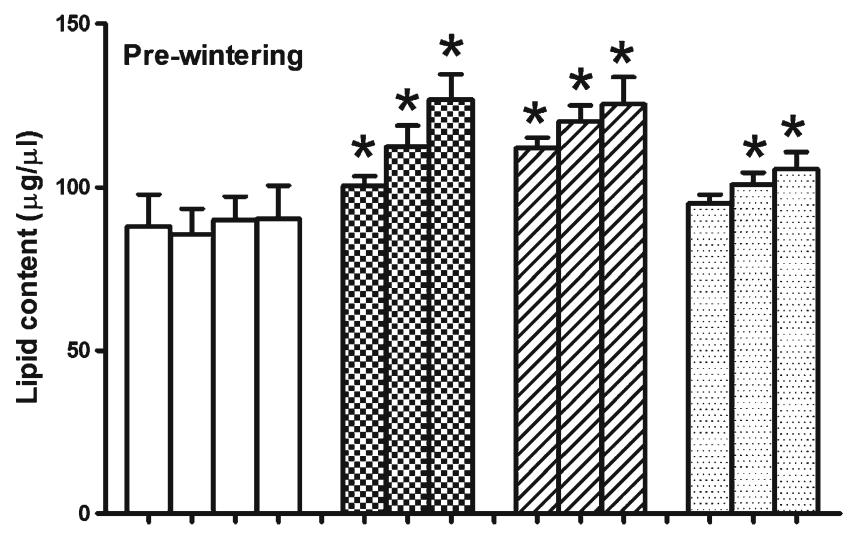

B

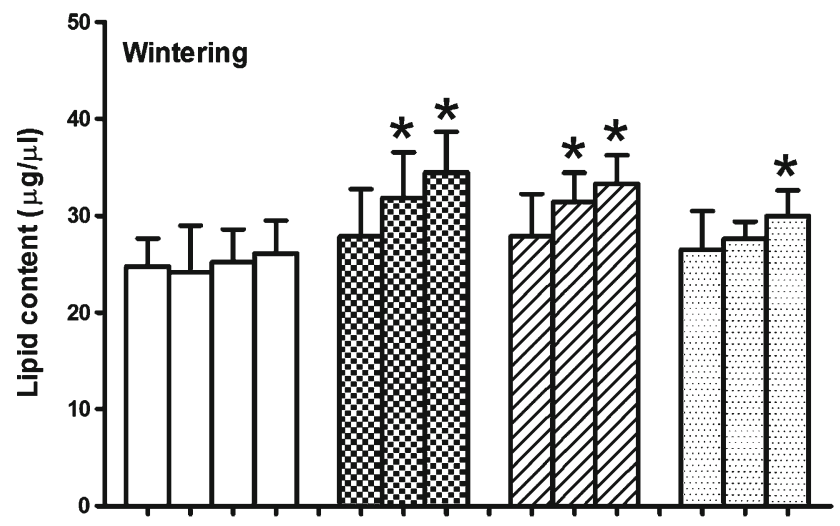

C

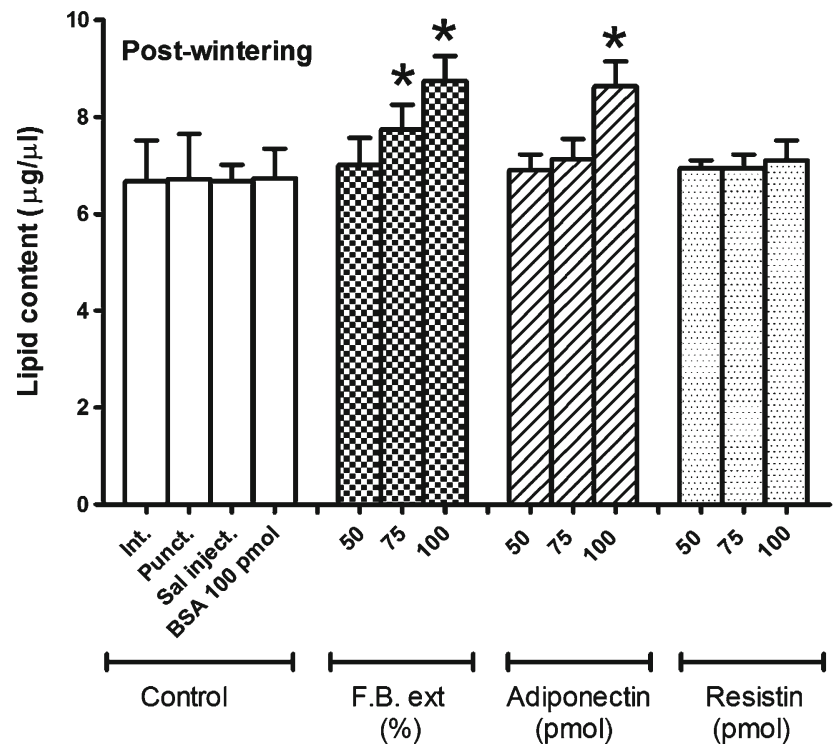


Figure 4 Correlation of lipid content in hemolymph with concentration of adiponectin (a) and resistin (b) in fat body and resistin and adiponectin (c) in fat body of $O$. bicornis females during over-wintering. The $x$-axis in (a) and (c) has been converted to $\log _{10}$ scale with actual adiponectin concentrations. Sixty-six pairs of data points were plotted for (a) with a Pearsons $r=0.748$ $(P<0.0001), 60$ pairs data points were plotted for (b) with a Pearsons $r=0.907$ $(P<0.0001)$ and 52 pairs of data points were plotted for $(\mathbf{c})$ with a Pearsons $r=0.913$ $(P<0.0001)$

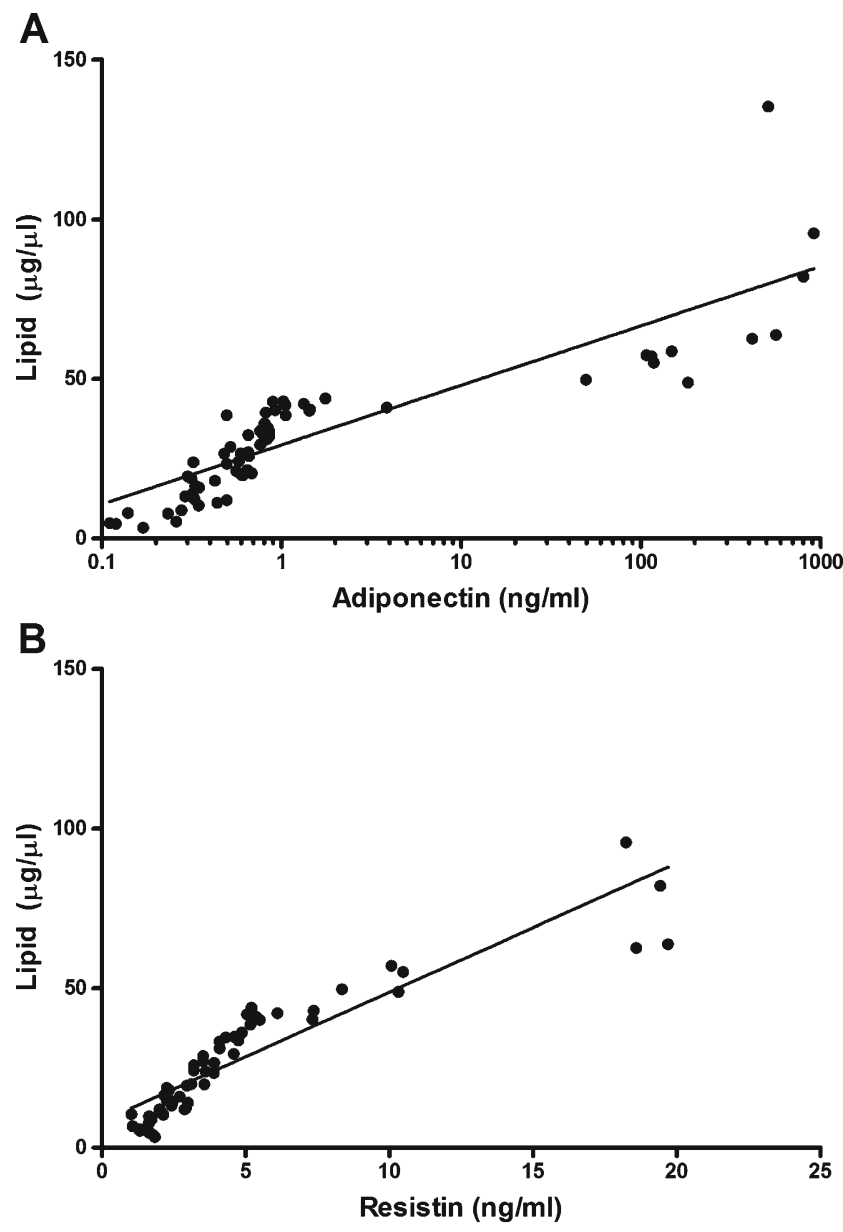

C

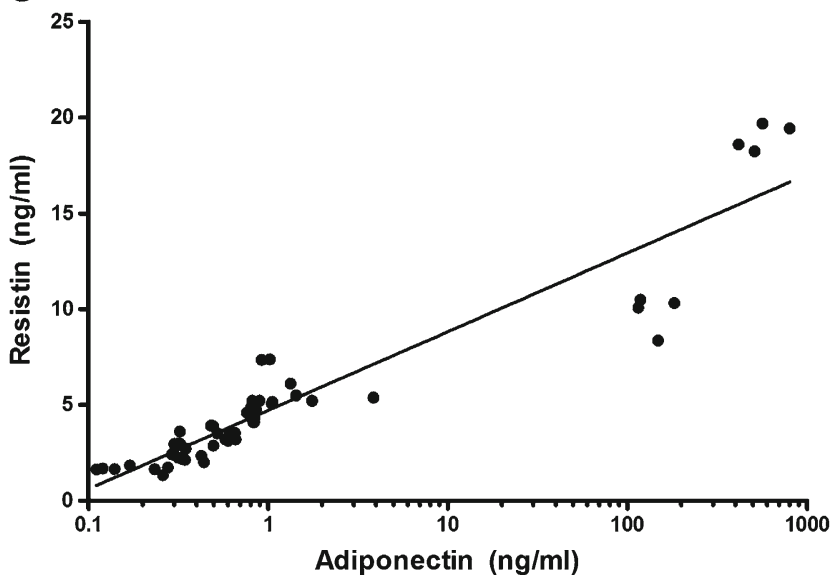

diapause adults decreases linearly with time spent in diapause. Similarly, storage protein content declines during diapause in larvae of the southwestern corn borer, Diatraea grandiosella (Chippendale 1973) and in adults of the Colorado potato beetle, Leptinotarsa 
decemlineata (Lefevere et al. 1989). Species may differ in their relative utilization of each reserve class during diapause. For example, the mobilization of fat reserves to fuel oxidative metabolism during diapause is evident in the low respiratory quotients (RQs, the ratio between $\mathrm{CO}_{2}$ production and $\mathrm{O}_{2}$ consumption), near 0.7 , exhibited by some insects (Adedokun and Denlinger 1985; Sgolastra et al. 2010). Patterns of reserve utilization can also change noticeably as individuals pass through different stages of diapause development. For example, total body fat decreases rapidly during the first half of diapause in pupae of the flesh fly Sarcophaga crassipalpis, while fat content remains relatively constant during the second half of diapause (Adedokun and Denlinger 1985). Conversely, fat-free dry mass decreases little during the first half of diapause and then drops rapidly during the second half of diapause in this species. This pattern suggests that diapausing $S$. crassipalpis pupae utilize fat stores as the primary metabolic fuel during the first half of diapause, and other substrates, perhaps carbohydrates or proteins, in the second half of diapause. We reported observing a similar situation in over-wintering $O$. bicornis females (Wasielewski et al. 2013). At the beginning, in September, the highest level of free lipds in hemolymph was recorded. During the first half of over-wintering (SeptemberNovember), females intensively utilized the fatty acids accumulated in hemolymph, as demonstrated by significant differences in free lipid concentration in particular months of the pre-wintering period (Wasielewski et al. 2013). Similarly, RQ values in the solitary bee Megachile rotundata are near 0.7 during the first 3 months of over-wintering but are higher (0.8-1.0) during the last 3 months, suggesting that patterns of substrate catabolism change from early to late diapause in this species as well (Yocum et al. 2005). In our previous study, a similar pattern to $M$. rotundata was also observed in $O$. bicornis with a change in metabolic reserves utilization as recorded by the percent differences in lipid concentration between two points of over-wintering, the start
(September) and the finish (March) (92.4\%) (Wasielewski et al. 2013). In another Megachilid species, a spring-flying solitary bee from North America, Osmia lignaria, the RQ during pre-wintering was $0.6-0.8$, indicating the likely use of triglycerides as the main energy substrate (Bosch et al. 2010; Sgolastra et al. 2010, 2011).

Nutrient utilization during diapause is a dynamic process, but we currently know little about the physiological processes used by diapausing insects to assess their nutrient reserves and regulate nutrient utilization. At present, the insulin signalling pathway, best known for its role in regulating carbohydrate and fat metabolism in mammals, is a highly conserved and promising candidate likely to play a major role in regulating reserves in insect diapause. Other promising candidates for diapause-associated nutrient regulation are AKH, neuropeptide F, the cyclic GMPdependent protein kinase for and AMPactivated protein kinase (AMPK) (Hahn and Denlinger 2007, 2011). With respect to AKHs, there is only one evidence available on the involvement of AKH in diapause metabolism (Socha and Kodrík 1999). In this work, it has been showed that brachypterous females of the firebug Pyrrhocoris apterus while diapausing as adults released approximately twice as much lipid into the hemolymph than non-diapause brachypterous females when injected with an equivalent quantity of either Locusta migratoria AKH-I or extracts of the $P$. apterus AKH producing glands. It is noteworthy that other candidates whose function can be compared with AKHs, adiponectin (Tsao et al. 2002) and resistin (Holcomb et al. 2000), peptide hormones (adipocytokines) were discovered in last decade from vertebrate adipose tissue. Adiponectin increases the oxidation of fat and thereby reduces the intracellular triglyceride content of liver and muscle and increases cellular sensitivity to insulin (Diez and Iglesias 2003; Nedvídkova et al. 2005). Another adipocytokine, resistin, accelerates simultaneously triglyceride lipolysis and fatty acids re-esterification (Ort et al. 2005; Nogueiras et 
al. 2010). Furthermore, the experiments with rats white adipose tissue cultured in vitro indicated that the levels of free fatty acids released into medium were significantly increased after exposure to resistin $(\mathrm{Gu}$ et al. 2007). However, no data are currently available on adiponectin-like and resistin-like peptides in insects or their activity. To our knowledge, this study provides the first evidence that the peptides similar to mammalian adipocytokines, adiponectin and resistin are able to regulate the free lipids in hemolymph during over-wintering time, including the diapause in O. bicornis. We confirmed the presence of these peptides using RIA/ELISA as well as immunoblots. After performing the tests, RIA for adiponectin-like peptides and ELISA for resistin-like peptides in three different times of over-wintering (prewintering, wintering and post-wintering), we did not detect any immunoreactivity in additional tissues tested: muscles, gut and brain (data not shown). It is possible that these newly discovered peptides could be structurally different from vertebrate adiponectin and resistin. Despite the structural differences, the mode of action seems to be similar. During consecutive months of wintering time (September-March), the concentration of both peptides in fat body homogenates decreased. Moreover, in tandem to changes in lipid content in hemolymph (as reported previously in Wasielewski et al. 2013), the first 3 months of pre-wintering time showed drastic reduction in the concentration of both peptides in the fat body. After the initial rapid decline, the content of both peptides in fat body homogenates gradually decreased in successive months. These peptides were also able to mobilize lipids into the hemolymph in a dose-dependent manner during pre-wintering and wintering periods. It is important to note that, the total lipid content in hemolymph and the adiponectin-like and resistin-like peptides concentration in fat body were positively correlated. Taken together, these results strongly suggest a possible role of adiponectin-like and/ or resistin-like peptides in regulation of free lipid concentration in hemolymph during overwintering of this solitary bee.
A deeper understanding of the physiological regulation of diapause-associated changes in metabolism in insects will require a careful biochemical and molecular dissection of probable candidates for regulation of the signalling and metabolic pathways. Judicious use of genomic, proteomic and metabolomic screening is necessary to identify new candidates playing regulatory roles in multiple well-characterized models for insect diapause.

\section{ACKNOWLEDGMENTS}

This work was supported by the Ministry of Science and Higher Education (NN311 298935) grant to O.W. and by start-up funds MSU\#269110-151250 (NK) from NSF, EPSCOR. The stay of $A B$ at Mississippi State University was partially supported by a travel grant from Nadace 'Nadání, Josefa, Marie a Zdeňky Hlávkových'.

OPEN ACCESS This article is distributed under the terms of the Creative Commons Attribution License which permits any use, distribution, and reproduction in any medium, provided the original author(s) and the source are credited.

Rôle potentiel de peptides fonctionnellement apparentés à l'adiponectine et à la résistine dans la régulation des niveaux lipidiques dans l'hémolymphe de femelles adultes hivernantes d'Osmia bicornis

Diapause / lipides libres / abeille solitaire / hivernation

Eine mögliche Rolle von Adiponectin- und Resistinähnlichen Peptiden bei der Regulierung der Lipidniveaus in der Hämolymphe überwinternder erwachsener Weibchen von Osmia bicornis

Diapause / freie Lipide / Überwinterung / Solitäre Biene

\section{REFERENCES}

Adedokun, T.A., Denlinger, D.L. (1985) Metabolic reserves associated with pupal diapause in the flesh fly, Sarcophaga crassipalpis. J. Insect Physiol. 31, 229-233 
Alquicer, G., Kodrik, D., Krishnan, N., Vecera, J., Socha, R. (2009) Activation of insect anti-oxidative mechanisms by mammalian glucagon. Comp. Biochem. Physiol. Part B. 152, 226-227

Arrese, E.L., Soulages, J.L. (2010) Insect fat body: energy, metabolism, and regulation. Annu. Rev. Entomol. 55, 207-225

Bednářová, A., Kodrík, D., Krishnan, N. (2013) Unique roles of glucagon and glucagon-like peptides: Parallels in understanding the functions of adipokinetic hormones in stress responses in insects. Comp. Biochem. Physiol. Part A. 164, 91-100

Bosch, J., Kemp, W.P. (2000) Development and emergence of the orchard pollinator Osmia lignaria (Hymenoptera: Megachilidae). Environ. Entomol. 29, 8-13

Bosch, J., Sgolastra, F., Kemp, W.P. (2010) Timing of eclosion affects diapause development, fat body consumption and longevity in Osmia lignaria, a univoltine, adult-wintering solitary bee. J. Insect Physiol. 56, 1949-1957

Chippendale, G.M. (1973) Diapause of the southwestern corn borer, Diatraea grandiosella: utilization of fat body and hemolymph reserves. Entomol. Exp. Appl. 16, 395-406

Danks, H.V. (1987) Insect Dormancy: An Ecological Perspective. Biological Survey of Canada, Ottawa

De Wilde, J., Staal, G.B., De Kort, C.A.D., Baard, G. (1968) Juvenile hormone titre in the haemolymph as a function of photoperiodic treatment in the adult Colorado potato beetle (Leptinotarsa decemlineata). Proc. K. Ned. Akad. Wet. C 71, 321-326

Denlinger, D.L. (2002) Regulation of diapause. Annu. Rev. Entomol. 47, 93-122

Diez, J.J., Iglesias, P. (2003) The role of novel adipocyte-derived hormone adiponectin in human disease. Eur. J. Endocrinol. 148, 293-300

Ellers, J., van Alphen, J.M. (2002) A trade-off between diapause duration and fitness in female parasitoids. Ecol. Entomol. 27, 279-284

Gäde, G. (2004) Regulation of intermediary metabolism and water balance of insects by neuropeptides. Annu. Rev. Entomol. 49, 93-113

Gäde, G., Auerswald, L. (2003) Mode of action of neuropeptides from the adipokinetic hormone family. Gen. Comp. Endocr. 132, 10-20

Gäde, G., Hoffmann, K.H., Spring, J.H. (1997) Hormonal regulation in insects: facts, gaps, and future directions. Physiol. Rev. 77, 963-1032

Giejdasz, K., Wilkaniec, Z. (2002) Individual development of the red mason bee (Osmia rufa L., Megachilidae) under natural and laboratory conditions. J. Apic. Sci. 46, 51-57

Gu, N., Han, S.-P., Fei, L., Pan, X.-Q., Guo, M., Chen, R.-H., Guo, X.-R. (2007) Resistin-binding peptide antagonizes role of resistin on white adipose tissue. Acta Pharmacol. Sin. 28, 221-226
Hahn, D.A., Denlinger, D.L. (2007) Meeting the energetic demands of insect diapause: nutrient storage and utilization. J. Insect Physiol. 53, 760-773

Hahn, D.A., Denlinger, D.L. (2011) Energetics of insect diapause. Annu. Rev. Entomol. 56, 103-121

Hallmen, M. (1988) Die Besiedelung unterschidlicher künstlicher Nisthilfen durch Osmia rufa L. (Hymenoptera: Megachilidae). Nachr. Entomol. Ver. Apollo 9, 199-112

Herman, W.S., Tatar, M. (2001) Juvenile hormone regulation of longevity in the migratory monarch butterfly. Proc. Biol. Sci. 22, 2509-2514

Holcomb, I.N., Kabakoff, R.C., Chan, B., Baker, T.W., Gurney, A., Henzel, W., Nelson, C., Lowman, H.B., Wright, B.D., Skelton, N.J., Frantz, G.D., Tumas, D.B., Peale Jr., F.V., Shelton, D.L., Hebert, C.C. (2000) FIZZ1, a novel cysteine-rich secreted protein associated with pulmonary inflammation, defines a new gene family. EMBO J. 19, 4046-4055

Isabel, G., Martin, J.-R., Chidami, S., Veenstra, J.A., Rosay, P. (2005) AKH-producing neuroendocrine cell ablation decreases trehalose and induces behavioral changes in Drosophila. Am. J. Physiol.-Reg. I 288, 531-538

Kim, S.K., Rulifson, E.J. (2004) Conserved mechanisms of glucose sensing and regulation by Drosophila corpora cardiaca cells. Nature 431, 316-320

Kodrík, D., Marco, H.G., Šimek, P., Socha, R., Štys, P., Gäde, G. (2010) The adipokinetic hormones of Heteroptera: A comparative study. Physiol. Entomol. 35, 117-121

Koštál, V. (2006) Eco-physiological phases of insect diapause. J. Insect Physiol. 52, 113-127

Krafsur, E.S., Moon, R.D., Kim, Y., Rosales, A.L. (1999) Dynamics of diapause recruitment in populations of the face fly, Musca autumnalis. Med. Vet. Entomol. 13, 337-348

Kristjansson, K. (1992) Development of solitary bees as crop pollinators, pp. 91-109. Proceedings of an EC workshop, Brussels, Belgium

Laemmli, U.K. (1970) Cleavage of structural proteins during the assembly of the head of bacteriophage T4. Nature. 227, 680-685

Lefevere, K.S., Koopmanschap, A.B., DeKort, C.A.D. (1989) Changes in the concentrations of metabolites in hemolymph during and after diapause in female Colorado potato beetle, Leptinotarsa decemlineata. J. Insect Physiol. 35, 121-128

Macrae, T.H. (2005) Diapause: diverse states of developmental and metabolic arrest. J. Biol. Res. 3, 3-14

McTernan, P.G., Kusminski, C.M., Kumar, S. (2006) Resistin. Curr. Opin. Lipidol. 17, 170-175

Nedvídkova, J., Smitka, K., Kopsky, V., Hainer, V. (2005) Adiponectin, an adipocyte-derived protein. Physiol. Res. 54, 133-140

Nogueiras, R., Novelle, M.G., Vazquez, M.J., Lopez, M., Dieguez, C. (2010) Resistin: regulation of food 
intake, glucose homeostasis and lipid metabolism. Endocr. Dev. 17, 175-184

Ort, T., Arjona, A.A., MacDougall, J.R., Nelson, P.J., Rothenberg, M.E., Wu, F., Eisen, A., Halvorsen, Y.D.C. (2005) Recombinant human FIZZ3/Resistin stimulates lipolysis in cultured human adipocytes, mouse adipose explants and normal mice. Endocrinology 146, 2200-2209

Rust, R., Torchio, P., Trostle, G. (1989) Late embryogenesis and immature development of Osmia rufa cornigera (Rossi) (Hymenoptera: Megachilidae). Apidologie 20, 359-367

Saunders, D.S. (2000) Larval diapause duration and fat metabolism in three geographical strains of the blow fly, Calliphora vicina. J. Insect Physiol. 46, 509-517

Satake, S., Kawabe, Y., Mizoguchi, A. (2000) Carbohydrate metabolism during starvation in the silkworm Bombyx mori. Arch. Insect Biochem. 44, 90-98

Sgolastra, F., Bosch, J., Molowny-Horas, R., Maini, S., Kemp, W.P. (2010) Effect of temperature regime on diapause intensity in an adult - wintering Hymenopteran with obligate diapause. J. Insect Physiol. 56, 185-194

Sgolastra, F., Kemp, W.P., Buckner, J.S., Pitts-Singer, T.L., Maini, S., Bosch, J. (2011) The long summer: Pre-wintering temperatures affect metabolic expenditure and winter survival in a solitary bee. J. Insect Physiol. 57, 1651-1659

Socha, R., Kodrík, D. (1999) Differences in adipokinetic responses of Pyrrhocoris apterus (Heteroptera) in relation to wing dimorphism and diapause. Physiol. Entomol. 24, 278-284

Tasei, J.N. (1973a) Le comportement de nidification chez Osmia cornuta Latr. et Osmia rufa L. (Hymenoptera; Megachilidae). Apidologie 4, 195-225

Tasei, J.N. (1973b) Observations sur le développement d'Osmia cornuta Latr. et Osmia rufa L. (Hymenoptera, Megachilidae). Apidologie 4, 295-315

Tatar, M., Yin, C.M. (2001) Slow aging during insect reproductive diapause: why butterflies, grasshoppers and flies are like worms. Exp. Gerontol. 36, 723-738

Tsao, S.T., Lodish, H.F., Fruebis, J. (2002) ACRP30, a new hormone controlling fat and glucose metabolism. Eur. J. Pharmacol. 440, 213-221
Wasielewski, O., Giejdasz, K., Wojciechowicz, T., Skrzypski, M. (2011a) Ovary growth and protein levels in ovary and fat body during adult-wintering period in the red mason bee, Osmia rufa L. Apidologie 42, 749-758

Wasielewski, O., Wojciechowicz, T., Giejdasz, K., Krishnan, N. (2011b) Influence of methoprene and temperature on diapause termination in adult females of the over-wintering solitary bee, Osmia rufa L. J. Insect Physiol. 57, 1682-1688

Wasielewski, O., Wojciechowicz, T., Giejdasz, K., Krishnan, N. (2013) Overwintering strategies in the red mason solitary bee - physiological correlates of midgut metabolic activity and turnover of nutrient reserves in females of Osmia bicornis. Apidologie 44, 642-656

Wilkaniec, Z., Giejdasz, K. (2003) Suitability of nesting substrates for cavity-nesting bee Osmia rufa. J. Apic. Res. 42, 29-31

Wilkaniec, Z., Giejdasz, K., Fliszkiewicz, M. (2004) The influence of food amount consumed during the larval development on the body weight of the imago of the red mason bee (Osmia rufa L., Megachilidae). J. Apic. Sci. 48, 29-36

Wójtowski, F. (1979) Observations on the biology and utilization potential of the red mason bee Osmia rufa L. (Apoidea, Megachilidae). (in Polish). Roczniki AR Poznań 111, 203-208

Wójtowski, F., Wilkaniec, Z. (1978) Rearing and utilization of solitary bees settled in nest traps (in Polish). Instr. Wdroż. AR Poznań 1-10

Yocum, G.D., Kemp, W.P., Bosch, J., Knoblett, J.N. (2005) Temporal variation in overwintering gene expression and respiration in the solitary bee Mechachile rotundata. J. Insect Physiol. 51, 621629

Zera, A.J., Denno, R.F. (1997) Physiology and ecology of dispersal polymorphism in insects. Annu. Rev. Entomol. 42, 207-230

Zöllner, N., Kirsch, K. (1962) Über die quantitative Bestimmung von Lipoide (Mikromethode) mittels der vielen natürlichen Lipoiden (allen bekannten Plasmalipoiden) gemeinsamen Sulfo- phosphovanillin-Reaktion. Z. Ges. Exp. Medizin. 135, 545561 